\title{
Свген Сокол
}

доктор технічних наук, професор, член-кореспондент НАН України, ректор Національного технічного університету “Харківський політехнічний інститут”; Харків, Україна

ORCID: 0000-0003-1370-1482

E-mail:Sokol@kpi.kharkov.ua

\section{Олександр Пономарьов}

кандидат технічних наук, професор, професор кафедри педагогіки і психології управління соціальними системами ім. академіка I. Зязюна, Національний технічний університет

"Харківський політехнічний інститут"; Харків, Україна

ORCID: 0000-0003-4698-2620

E-mail: palex37@ukr.net

\section{ЦІЛЬОВА ПІДГОТОВКА ЕЛІТИ І ЛІДЕРІВ В УМОВАХ ТЕХНІЧНОГО УНІВЕРСИТЕТУ}

\begin{abstract}
Анотація: обгрунтовано зростання потреби суспільного виробництва в лідерах, зумовленої динамічним розвитком промисловості і прискоренням циклу старіння та зміни технологій. Показано, що організацію підготовки цих лідерів і нової гуманітарно-технічної еліти доцільно здійснювати в закладах вищої освіти інженерного профілю. Доведено, що з метою якісної підготовки еліти і лідерів як справжніх носіїв та організаторів науково-технічного й соціального прогресу в умовах становлення індустрії 4.0 вкрай необхідно переходити і до освіти 4.0. Проаналізовано досвід практики з підготовки еліти і лідерів в Національному технічному університеті "Харківський політехнічний інститут".

Ключові слова: лідер, потреби суспільного виробництва, індустрія 4.0, освіта 4.0, гуманітарно-технічна еліта.
\end{abstract}

\section{Yevgen Sokol}

doctor of technical sciences, professor, a corresponding member of NAS Ukraine, rector of the National Technical University "Kharkiv Politechni Institute"; Kharkiv, Ukraine E-mail: Sokol@kpi.kharkov.ua

\section{Olexandr Ponomaryov}

professor, candidate of technical sciences, professor of the pedagogy and psychology of social systems management department by the academician I. Zyazyun, National Technical University

"Kharkiv Politechnic Institute"; Kharkiv, Ukraine

E-mail: palex37@ukr.net

\section{TARGET TRAINING OF ELITE AND LEADERS IN THE CONDITIONS OF TECHNICAL UNIVERSITY}

Abstract: the growth of the need for social production in the leaders due to the dynamic development of industry and the acceleration of the cycle of aging and technological change is justified. It is shown that the organization of training of these leaders and the new humanitarian and technical elite should be carried out in higher education institutions of engineering profile. It is proved that in order to qualitatively train the elite and leaders as real carriers and organizers of scientific, technical and social progress in the conditions of formation of industry 4.0 it is extremely necessary to pass to education 4.0.

(C) Свген Сокол, Олександр Пономарьов, 2021 
The experience of practice in training elite and leaders at the National Technical University "Kharkiv Polytechnic Institute" is analyzed.

Key words: leader, needs of social production, industry 4.0, education 4.0, humanitarian and technical elite.

\section{Евгений Сокол, Александр Пономарев}

\section{ЦЕЛЕВАЯ ПОДГОТОВКА ЭЛИТЫ И ЛИДЕРОВ В УСЛОВИЯХ ТЕХНИЧЕСКОГО УНИВЕРСИТЕТА}

Аннотащия: обоснован рост потребности общественного производства в лидерах, обусловленный динамичным развитием промышленности и ускорением цикла старения и смены технологий. Показано, что организацию подготовки этих лидеров и новую гуманитарнотехническую элиту целесообразно осуществлять в учреждениях высшего образования инженерного профиля. Доказано, что в целях качественной подготовки элиты и лидеров как настоящих носителей и организаторов научно-технического и социального прогресса в условиях становления индустрии 4.0 крайне необходимо переходить к образованию 4.0. Проанализирован опыт практики подготовки элиты и лидеров в Национальном техническом университете "Харьковский политехнический институт".

Ключевые слова: лидер, потребности общественного производства, индустрия 4.0, образование 4.0 , гуманитарно-техническая элита.

\section{Yevgen Sokol, Olexandr Ponomaryov}

An extended abstract of the paper on subject of:

\section{"Target training of Elite and Leaders in the conditions of Technical University"}

Problem setting. A feature of today is the rapid change of applied technologies. This situation causes the growth of social needs in real leaders and highly professional elites. Ensuring their proper training appears at the level of an important problem of higher education. The global trend of transition to the 4.0 economy necessitates a new quality of training of elites and leaders. The implementation of this training requires the creation of a level 4.0 education system. Proper training and personal development of leaders who are able to successfully and effectively move science and technology can be most effectively carried out in the system of institutions of higher technical education. After all, this system is distinguished by the specificity of tasks and a clear practical orientation of the educational process. These features enhance the effectiveness of the influence of leaders on staff, contribute to the formation of a true production elite.

Recent research and publication analysis. V. Babayev, O. Bandurka, B. Bass, R. Boyatsis, D. Goulman, N. Iliash, S. Kalashnikova, R. Case, J. Kotter study a wide range of aspects of leadership that are extremely important for pedagogical theory and practice of education,
O. Ponomaryov, O. Romanovsky, V. Sheinov and others. J. Hunt, S. Cossen, A. Lawton and E. Rose study the personal qualities and characteristics of a leader. They substantiate a coherent set of ten such qualities.

Chapman $R$. analyzes the qualities necessary for a leader based on the results of studying the personal traits of employees of a number of government agencies in the UK. The role and importance of charisma significantly increase in the development of transformational leadership. Its essence and content are actively explored by B. Bass and R. Reggio [8], K. Blanchard, W. Moroz, O. Nestulya, J. Yakl and others. A significant contribution to the systematic study of the phenomenon of the leader's charisma and its main manifestations belongs to R. Gandapas [3].

From the standpoint of providing quality training of leaders, it is appropriate to mention the formation of a philosophy of creative leadership, the results of which are presented in the work of $P$. Kasse and R. Claudel [9]. E. Sokol systematically approaches the consideration of the training of professional leaders as an important task of higher education [5]. Values aspects of leadership are studied by K. Hodgkinson, G. Fairholm and 
S. Kuchmarski. They are based on a deep understanding of the essence of the phenomenon of value.

The ability to act effectively and influence people in conditions of risk and information uncertainty is important for a leader. Similar situations often occur in the management of the leader. SD Vermilion and his co-authors investigate the assessment of risk outcomes in engineering decisions made under uncertainty [14].

Paper objective of this article defines the main directions of professional training of the elite and leaders of engineering profile and substantiation of the need to develop and apply innovative pedagogical technologies that would ensure the relationship between industry and engineering education, including training of professional leaders and the formation of a new engineering elite, competitive in the labor market.

Paper main body. The effectiveness of joint activities of people and their achievement of its goals depends on the leadership qualities of the leader. Therefore, the innovative development of the economy must be accompanied by the appropriate development of goals, content and nature of training of leaders and their personal development. Training of leaders in the system of technical education has its own characteristics due to the wide variety of tasks and functions of their future professional activity. They must be both true professional leaders and authoritative leaders with an innovative nature of thinking and its strategic focus. This will ensure the efficiency of production and the value perception of staff belonging to this company or firm Industrial production is extremely dynamic.

Today, its development has reached a qualitatively new level, corresponding to the fourth industrial revolution or industry 4.0 and mass use in the production, in everyday life and in leisure of robotic devices and other cyberphysical systems that perform heavy, potentially dangerous and routine operations. A variety of devices based on artificial intelligence and automated production with control of all production processes in real time are widely used. The vast possibilities inherent in modern cyberphysical systems and those that until recently were written only by science fiction, today are realized by creating virtual models of real objects and processes of the physical world.

With the help of these models, cyberphysical systems successfully monitor the state of objects and the nature of the processes of their functioning. Based on the results of control, they make local decentralized decisions. At the same time, these systems can be integrated into complex networks and interact with each other in real time. In the world economy, including to some extent in Ukraine, there is a transition to fundamentally new high technologies. Ensuring the development of equipment and technologies of generation 4.0 and their effective use requires the training of specialists of a qualitatively new level. Their professional and social competence and personal development, general and professional culture, worldviews and spiritual world must meet the high requirements of the new economy as much as possible.

Leaders of the new era must have the skills, aspirations and willingness to shape change themselves in accordance with the defining trends of scientific, technological and social development. Therefore, Industry 4.0 determines the need for 4.0 education. This transition requires a new paradigm of education, primarily technical. Its meaning is to move from Industry 4.0 to 4.0 Universities, to train professionals who are professionally, socially and psychologically ready to work successfully in the space of high technology and quickly adapt to their possible drastic changes in the future. Staffing of the economy 4.0 is still very poorly implemented and does not have a clear target, logical-methodological, substantive and scientificmethodological justification. As a result, today all universities in Ukraine and most universities in other countries are still at stage 3.0. The mission of higher education is to advance the development of university education in comparison with the development of the economy. Only in this case can we really ensure the integrity and systemic nature of scientific, technological and social progress.

Malaysian researchers A. Shahrum and N. Hussein, convincingly write that "the fourth industrial revolution (IR 4.0) changed the landscape of educational innovations. It is based on the capabilities of artificial intelligence and digital physical structures and is controlled by them, which makes the human-machine interface more universal" $[13, p .315]$. They believe that in the future there will be many changes in the ways of teaching and learning, in its content and the role of teachers and students. The logic of education must be reversed so that the system corresponds to the student, not the student to the system. In this is very essence of personalization of education.

National Technical University "Kharkiv Polytechnic Institute" has won a high reputation 
in our country and in the world. It is characterized by a high level of professional training and sensitivity to innovation, to changing personnel needs of various spheres of public life. The system of engineering training is aimed at ensuring the appropriate level of highly qualified professional leaders and the formation of a fundamentally new, humanitarian and technical elite.

Conclusion of the research. 1. The world is changing rapidly and becoming innovative. The content of social production and people's way of life is becoming more complicated. The development of information and biocybernetic technologies and artificial intelligence is accelerating the formation of the fourth generation economy (IR 4.0). This changes the requirements for the education system for the training of adequate staffing of social production.

2. In the new social conditions, higher education must radically reconsider the goals, content and nature of training. Industry 4.0 requires a new quality of staff and necessitates a new educational paradigm at the 4.0 level.

Постановка проблеми у загальному вигляді та її зв'язок з важливими науковими і практичними завданнями. Особливістю сьогодення стала швидка зміна застосовуваних технологій. Ця ситуація зумовлює зростання суспільних потреб у справжніх лідерах та високопрофесійній еліті. Саме притаманний їм характер інноваційного мислення i його загальна стратегічна спрямованість забезпечують потужний вплив лідерів та еліти на прискорення науково-технічного прогресу. Належна ж професійна підготовка та особистісний розвиток лідерів, здатних успішно й ефективно рухати науку і техніку, найбільш ефективно може здійснюватися в системі закладів вищої технічної освіти. Адже цю систему відрізняють конкретність завдань i чітка практична спрямованість освітнього процесу.

Відповідно до Стратегії розвитку вищої освіти України на 2021-2031 роки основним завданням вищої технічної школи є професійна підготовка інженерів. Проте виявлення серед студентів потенційних лідерів та їхня наступна цільова підготовка не повинні й не можуть здійснюватися за рахунок зниження якості й рівня їхнього професіоналізму. Тому успішне виконання завдань із підготовки справжніх професіональних лідерів і належної еліти має розглядатися як вкрай важлива проблема,
Graduates must not only adapt quickly to change, but also create change, ensure the competitiveness of their activities.

3. Inertia, inherent in human nature, causes the unpreparedness of many people to the conditions of innovative development. Therefore, society feels the need for leaders who would activate people and inspire them to be active. It should contribute to their well-being, sociopsychological well-being and willingness to innovate. Leaders rely on the elite as the best professionals and bearers of morality and culture.

4. The social importance of the elite and leadership and the specifics of their functions require the organization of their targeted training. The experience of our university shows that such training should be carried out in a higher education institution of engineering profile. Its connection to production and participation in the development of Industry 4.0 creates clear guidelines for the transition to 4.0 education and the technical and technological prerequisites for the training of elite and level 4.0 leaders.

ефективне розв'язання якої вимагає чіткості, наполегливості та відповідальності, яке потає важливим доповненням до фахової підготовки інженера відповідно до вимог суспільного виробництва.

Глибинна сутність цієї досить складної проблеми полягає в тому, що цілі й характер промисловості як основного джерела життєзабезпечення людини і суспільства швидко, а часто й кардинально змінюються. Тому лідери повинні належним чином спрямовувати людей на швидке оволодіння принципово новими технологіями й ефективно їх використовувати. При цьому лідер має спиратися на кращих працівників, які й являють собою справжню еліту.

Аналіз останніх досліджень і публікацій, у яких започатковано розв'язання цієї проблеми і на які спираєть автор. Істотна роль феномена лідерства в забезпеченні суспільного життя обумовила значну увагу й пильний інтерес до нього з боку вчених найрізноманітніших спеціальностей - психологів i педагогів, соціологів і фахівців у галузі управління соціальними системами. Досить широкий спектр аспектів лідерства, вкрай важливих для педагогічної теорії i практики освіти досліджують В. Бабаєв, О. Бандурка, Б. Басс, С. Бочарова, Р. Бояціс, Д. Гоулман, Т. Гура, Н. Іліаш, С. Калашникова, О. Пономарьов, 
Дж. Коттер, О. Романовський, В. Шейнов, Р. Кейс та інші. Для ефективної організації цільової підготовки еліти і лідерів у системі освіти вкрай необхідно розуміти, розвиток яких особистісних рис і якостей слід забезпечувати. Їх сукупність як своєрідна модель лідера чи представника еліти виступає орієнтиром змісту й характеру навчально-виховного процесу. Дослідженню особистісних якостей і характеристик лідера присвячені роботи Дж. Ханта, С. Коссена, А. Лоутона та Е. Роуза, які наводять i обгрунтовують цілісну сукупність із десяти таких якостей. Р. Чапмен аналізує необхідні для лідера якості за результатами вивчення особистісних рис працівників низки урядових установ Великобританії. О. Віханський поділяе всю множину необхідних якостей лідера на три групи: інтелектуальні здібності, риси характеру та набуті уміння [2].

Особливий інтерес дослідників викликають також проблеми сутності і природи харизми і харизматичного лідерства, оскільки воно забезпечує найбільш ефективний вплив лідера на своє оточення. Роль і значення харизми істотно зростають в умовах розвитку трансформаційного лідерства. Його сутність $\mathrm{i}$ зміст активно досліджують Б. Басс та Р. Ріджіо [8], К. Бланшар, В. Мороз, О. Нестуля, Дж. Якл та інші. Істотний внесок у системне дослідження феномену харизми лідера та його основних проявів належить Р. Гандапасу [3]. 3 позицій забезпечення якісної підготовки фахівців-лідерів за доцільне згадати формування філософії креативного лідерства, результати якого наведено в роботі П. Кассе та
Р. Клоделя [9]. Системно підходить до розгляду підготовки професіоналів-лідерів як важливого завдання вищої школи $€$. Сокол [5].

Цікавими й важливими для теорії лідерства і практики цільової підготовки лідерів в системі вищої освіти є дослідження, Дж. Конже і Р. Канунгу. Їхні роботи присвячені актуальним проблемам харизматичного лідерства, визначення поведінкових атрибутів $\mathrm{i}$ можливостей їх вимірювання [10]. Для лідера важливою $\epsilon$ здатність ефективно діяти i впливати на людей в умовах ризику та інформаційної невизначеності. Подібні ж ситуації часто зустрічаються в процесі управлінської діяльності лідера. С. Вермійон і його співавтори досліджують оцінки результатів ризику в інженерних рішеннях, прийнятих в умовах невизначеності [14].

Феномен парадоксів харизматичного лідерства 3 системних позицій аналізують О. Романовський і О. Пономарьов. Вони переконані, що для цих парадоксів "характерним $€$ те, що вони обумовлені складною і суперечливою природою феномена харизми. Вона певною мірою виступає парадоксальним явищем, оскільки, з одного боку, харизма в більшості випадків властива тій чи іншій людині від природи і являє собою своєрідний дар. Однак з іншого боку, іiі розвиток і реалізація можуть істотно залежати від ряду об'єктивних і суб'єктивних факторів, від зовнішнього середовища, в першу чергу від характеру соціокультурного простору, в координатах якого і протікають життя і діяльність лідеpa" $[4$, c. 52]. Наочно уявлення процесу розвитку харизми можна представити у вигляді рис.1.

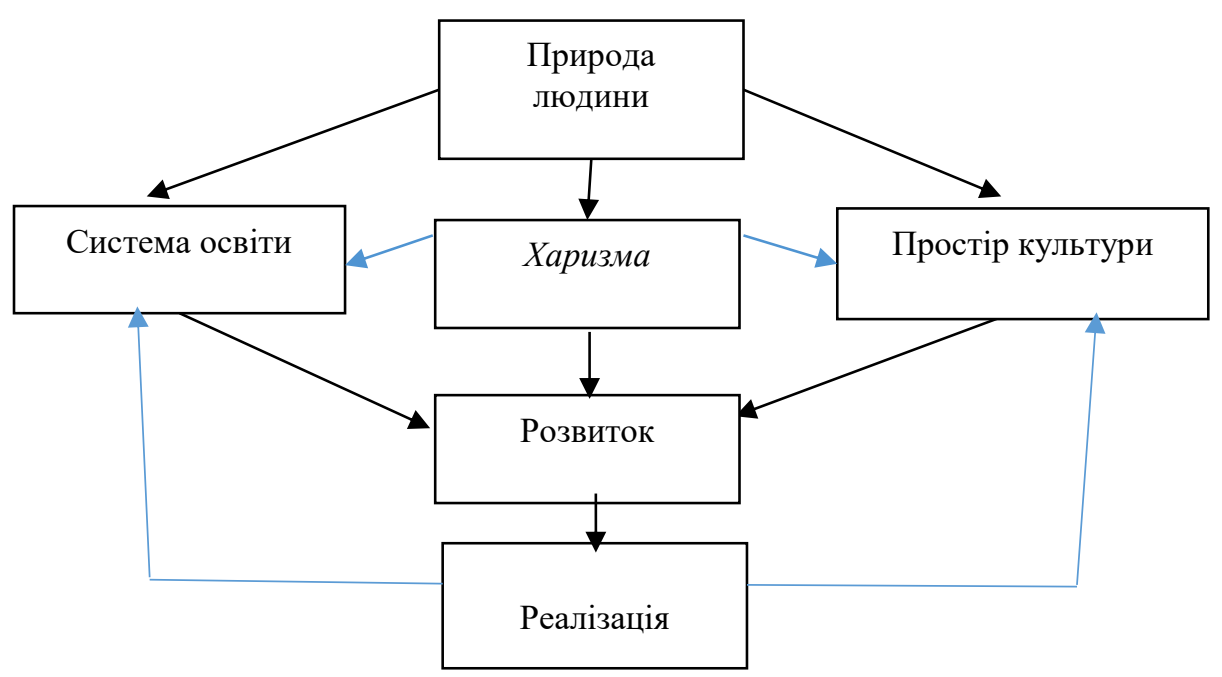

Рис. 1. Процес розвитку харизми 
Роботи, які висвітлюють результати дослідження ціннісних аспектів сучасних теорій лідерства, належать К. Ходжкінсону, Г. Фейрхольму, Т. та С. Кучмарським. Вони виходять із глибинного розуміння сутності самого феномену цінності, яке започаткували ще Діоген Лаертський, а пізніше Т. Гоббс i Б. Спіноза. Розвиток досліджень цінностей та їхній зв'язок 3 лідерством здійснювали М. Вебер, Ф. Знанецький, К. Роджерс, М. Рокич, Д. Леонтьєв, У. Томас та інші.

Виділення не вирішених раніше частин загальної проблеми, котрим присвячується дана стаття. В умовах стрімкого розвитку науково-технічного прогресу й інноваційного характеру еволюції самого суспільства і суспільного виробництва промисловість лишається однією 3 його найважливіших сфер, які забезпечують життєдіяльність людини і суспільства. Кадрове ж забезпечення промисловості, яка швидко змінюється, готує система технічної освіти. Проте недостатньо дослідженим є питання з цільової підготовки еліти і лідерів інженерного профілю. Між тим в Національному технічному університеті "Харківський політехнічний інститут" накопичено достатньо цікавий досвід такої підготовки. Він може бути корисним для інших закладів вищої технічної школи й системи вищої освіти взагалі.

Формулювання цілей статті (постановка завдання). Метою дослідження виступає прагнення авторів узагальнити досвід цільової підготовки еліти і лідерів в умовах технічного університету. Серед основних завдань дослідження виділяємо: розкриття характерних особливостей сучасного етапу розвитку промисловості, визначення основних напрямків професійної підготовки еліти і лідерів інженерного профілю, обгрунтування необхідності розробки і застосування інноваційних педагогічних технологій та забезпечення взаємозв'язку розвитку промисловості й інженерної освіти, в тому числі підготовки лідерівпрофесіоналів із формуванням нової інженерно-технічної еліти, конкурентоспроможної на ринку праці.

Виклад основного матеріалу дослідження 3 повним обгрунтуванням отриманих наукових результатів. Ефективна організація спільної діяльності людей та успішне досягнення ними заздалегідь визначених цілей істотною мірою залежить від лідерських якос- тей керівника або хоча б від наявності в колективі неформального лідера. При цьому вкрай важливо, щоб лідер був професіоналом. Ось чому інноваційний розвиток будь-якої галузі промисловості повинен супроводжуватись відповідним розвитком цілей, змістом і характером професійної підготовки лідерів інженерного профілю та їхнього особистісного розвитку.

У зв'язку 3 цим промислові підприємства, незалежно від форми їхньої власності, пред'являють особливі вимоги до підготовки лідерів і розвитку їхніх специфічних лідерських якостей. Це обумовлено тим, що основну частину не тільки їх технічного, але також і управлінського персоналу складають саме люди з інженерною освітою. Більш того, підготовка лідерів у системі технічної освіти має свої характерні особливості, зумовлені широким різноманіттям тих завдань і функцій, які їм доведеться виконувати під час здійснення їхньої майбутньої професійної діяльності. Іншими словами, ці люди повинні бути як справжніми лідерами-професіоналами, так і авторитетними керівниками 3 інноваційним характером мислення і його стратегічною спрямованістю задля і забезпечення належного рівня ефективності виробництва, i формування ціннісного сприйняття персоналом підприємства, фірми чи організації своєї приналежності до даного колективу.

Однак індустріальне виробництво надзвичайно динамічне, розвиток якого фактично перейшов на якісно новий рівень. Bсе це дає вагомі підстави говорити про перехід до четвертої промислової революції або індустрії 4.0. Серед іiі характерних особливостей виділяють:

- розробку і використання високих технологій із одночасним відносно швидким старінням і оновленням заради отримання конкурентних переваг;

- масове використання у виробництві, побуті та дозвіллі робототехнічних пристроїв та інших кіберфізичних систем, на які покладається виконання важких, потенційно небезпечних та рутинних операцій;

- застосування найрізноманітніших пристроїв, створених на основі штучного інтелекту;

- автоматизовані виробництва 3 керуванням усіма виробничими процесами в режимі реального часу і з адаптацією управлінських впливів відповідно до тих змін, що зумовлені 
зовнішніми умовами;

- чітку природоохоронну спрямованість використовуваних технологій і виробництв, яка поєднується 3 формуванням високої екологічної компетенції і свідомості персоналу;

- використання технології інтернету речей. Широкі можливості, притаманні сучасним киберфізичним системам й такі, про які донедавна писали тільки фантасти, сьогодні реалізуються шляхом створення віртуальних моделей реальних об' єктів і процесів фізичного світу. За допомогою цих моделей кіберфізичні системи успішно здійснюють контроль стану об'єктів і характер процесів їхнього функціонування. На підставі результатів контролю вони приймають локальні децентралізовані рішення, водночас об'єднуючись у складні мережі та взаємодіючи між собою в режимі реального часу.

Слід підкреслити, що кіберфізичним системам властиві здатності самонастроювання і самонавчання. Взагалі в індустрії 4.0 істотну роль відіграють інтернет-технології. Завдяки розвиненому інтерфейсу саме вони забезпечують необхідні й ефективні комунікації між персоналом i технікою. Підприємства, що працюють із технологіями 4.0, можуть створювати продукцію в повній відповідності 3 індивідуальними вимогами i побажаннями замовника, оптимізувати собівартість виробництва при високому рівні якості.

У світовій економіці, в тому числі певною мірою і українській, сьогодні відбувається відчутний перехід до використання принципово нових високих технологій. Їхня поява знаменує становлення четвертої індустріальної революції. Належне забезпечення не тільки успішної розробки техніки і технологій покоління 4.0, але i їх ефективного використання вимагає підготовки фахівців принципово нового якісного рівня. Рівень їхньої професійної і соціальної компетентності та особистісний розвиток, загальна і професійна культура, світоглядні позиції й духовний світ максимальною мірою повинні задовольняти високим вимогам нової економіки.

В той же час їхні професійні і особистісні якості повинні забезпечувати успішну адаптацію фахівців до неминучих змін в техніці i технологіях і в суспільних відносинах. Лідерам ж нової епохи повинні бути притаманні вміння, прагнення і готовність самим формувати зміни відповідно до визначальних тенден- цій науково-технічного і соціального розвитку. Ось чому індустрія 4.0 з усією необхідністю обумовлює нагальну потребу формування відповідної освіти 4.0. Більш того, такий інноваційний перехід зажадає створення принципово нової пара-дигми освіти, передусім технічної. Іншими словами, сенс цієї парадигми має полягати у переході від індустрії 4.0 до університетів 4.0, у підготовці фахівців професійно, соціально і психологічно готових не тільки успішно працювати у просторі високих технологій сьогодення, але й швидко адаптуватися до їхніх можливих, навіть кардинальних змін у майбутньому.

Уявляється цілком очевидною необхідність своєчасного i якісного кадрового забезпечення економіки 4.0. Однак у практичній діяльності освіти вона реалізується ще не просто вкрай слабо, але, на жаль, ще й не має чіткого цільового, логіко-методологічного, змістовного та науково-методичного обгрунтування. В результаті склалася ситуація, за якої сьогодні всі університети України і більшість університетів інших країн світу перебувають ще на стадії 3.0, в той час як світова економіка активно і 3 широким охопленням практично всіх галузей суспільного виробництва переходить в індустрію 4.0.

В той же час суспільна місія вищої школи має чітко полягати у забезпеченні випереджаючого розвитку університетської освіти в порівнянні 3 розвитком економіки. Адже тільки в такому випадку виникає реальна можливість забезпечити дійсно цілісність і системний характер науково-технічного i соціального прогресу, послідовне його здійснення. Ось чому перед вищою школою з усією гостротою постає надзвичайно важливе й відповідальне завдання з прискорення й посилення інтенсивності переходу до ідеології освіти 4.0 і практики іiі здійснення. Загальна схема цього процесу наведена на рис. 2 .

Надзвичайно важливим завданням університетів у контексті досліджуваного питання виступає також істотне підвищення рівня і значущості науково-дослідної роботи, в тому числі в галузі фундаментальних і соціально-гуманітарних наук. Адже реальне випередження розвитку економіки система вищої освіти може забезпечити передусім за рахунок розробки інноваційних технологій, що базуються на нових фізичних ефектах. А відкриття, вивчення і з'ясування можливостей 


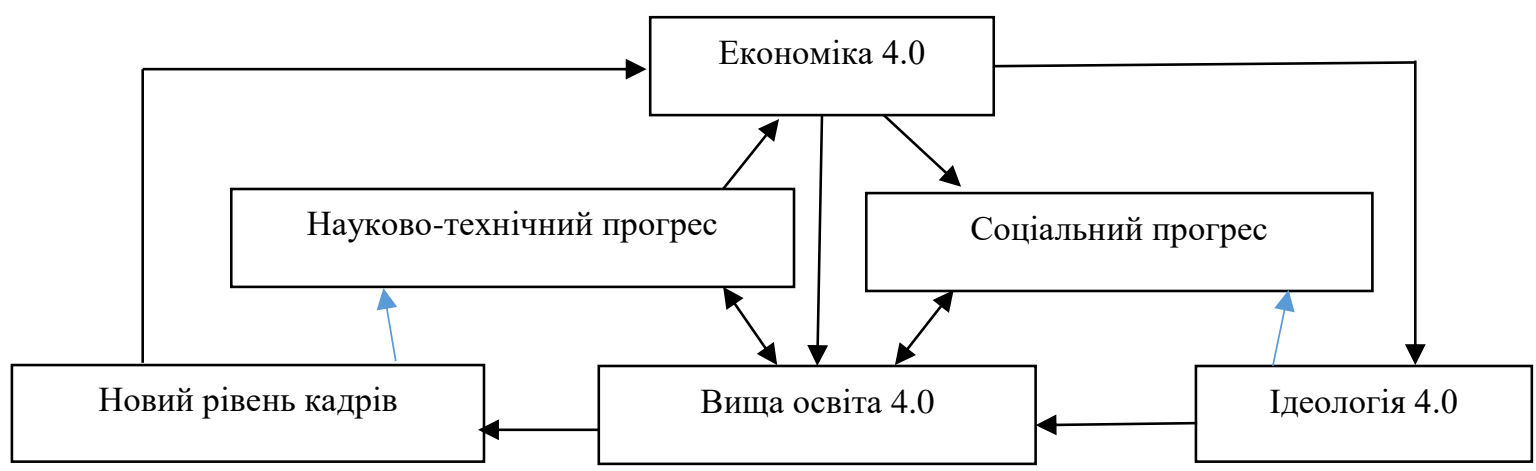

Рис. 2. Прочес переходу до освіти 4.0

практичного використання цих ефектів i становить сутність і мету, зміст і характер фундаментальних наук і одночасно предмет відповідної дослідницької діяльності науковопедагогічного персоналу.

Істотну роль в розробці та реалізації загальної стратегії освіти 4.0 відіграє також соціально-гуманітарна підготовка фахівців. Вона особливо важлива для виявлення потенційних лідерів та організації системної педагогічної діяльності з цілеспрямованого розвитку їхніх специфічно лідерських особистісних рис i якостей. Разом із тим вивчення соціально-гуманітарних дисциплін виступає одним iз визначальних чинників розвитку національної еліти i формування якостей, необхідних їі представникам для успішної та ефективної командної діяльності. Взагалі в системі завдань освіти 4.0 поряд із забезпеченням професійної компетентності особливого значення набувають загальна і професійна культура, життєві цілі й цінності фахівців, яких вона готує, та їхній духовний світ.

Як свідчить практика країн із інноваційною економікою, що грунтується на принципах індустрії 4.0, успішний розвиток значною мірою залежить від якості гуманітарнотехнічної еліти. Тому їі формування і виховання виступає важливим завданням освіти. Високий рівень професіоналізму цієї еліти у поєднанні 3 культурою, морально-етичними принципами i переконаннями, 3 порядністю й відповідальністю сприяє не тільки науково-технічному й технологічному, а й соціальному прогресу.

Водночас у повній відповідності зі своїми сенсом, місією і призначенням представники гуманітарно-технічної еліти прагнуть до формування, розвитку і належного функціонування громадянського суспільства i верхо- венства права. Вони забезпечують подолання корупції, підвищення рівня добробуту й соціально-психологічного настрою людей, досягнення суспільної злагоди.

Малайзійські дослідники А. Шахрум та Н. Хуссин, переконливо пишуть, що “четверта промислова революція (IR 4.0) змінила ландшафт освітніх інновацій. Вона грунтується на можливостях штучного інтелекту i цифрових фізичних структур і контролюється ними, що робить людино-машинний інтерфейс більш універсальним". На глибоке переконання цих авторів, “швидка революція в інноваціях дала нову модель освіти на майбутнє - Освіта 4.0. Підготувати випускників до майбутнього життя і роботи, досягнутої IR 4.0, де більш розумні роботи витісняють людей у певних сферах діяльності, освіта повинна навчити використовувати доречну інформацію і здатності, які не можуть бути замінені роботами" [13, с. 315].

Ці дослідники небезпідставно підкреслюють, що в майбутньому буде багато змін у способах викладання і навчання. До них вони відносять зміст навчання, ролі викладачів і студентів. На їхнє переконання, сама логіка систем освіти повинна бути перевернута так, щоб система відповідала учню, а не учень системі. В цьому вони вбачають саму сутність персоналізації освіти.

Вважаємо за необхідне звернути увагу, що донедавна Малайзія належала до бідних и недостатньо розвинених у технологічному плані країн. А сьогодні в країні сформована i чітко виконується науково-технічна політика, яка регулюється Міністерством науки, технології та інновацій. Вона зосереджена переважно на таких п'яти основних перспективних сфеpax: біотехнологія, інформаційно-комунікацій- 
ні технології, промисловість, море, космічні дослідження. Уже напередодні нового тисячоліття 54\% промислового експорту країни становила частка високотехнологічної продукціiі. Зокрема, Малайзія є одним із найбільших у світі експортерів напівпровідникової техніки, електричних товарів і продукції інформаційнокомунікаційних технологій. Швидко в країні розвивається і вища освіта.

Науково-педагогічний склад університетів Малайзії, як і інших держав, які сьогодні активно розвивають економіку 4.0, виконує серйозну науково-дослідницьку роботу. У числі напрямків їхнього інтересу помітне місце належить і проблемам освіти, включаючи цільову підготовку лідерів. Наприклад, А. Садхі та Ф. Мостафаві Рад аналізують роль лідерства, орієнтованого на знання, в управлінні знаннями та інноваціями [12]. С. Занда досліджує процеси створення ефективних практик управління та лідерства [15]. Оригінальну технологію гнучких навчальних маршрутів на основі концептуальних карт пропонують О. Агудело і Дж. Салінас [7].

Особливий інтерес для нас являє концептуальна дискусія на тему “Освіта 4.0”, яка розгорнулася на Міжнародній конференції 3 викладання, оцінки та навчання для інженерних наук в Австралії. Ініціаторами цієї дискусії виступили П. Клопп та Дж. Абке [11]. Взагалі найближчим часом варто очікувати потужний сплеск публікацій із проблем розвитку освіти 4.0 та його характерних особливостей, можливостей і переваг. Тим більше, що вони стимулюватимуть дослідження теоретичних основ i педагогічної практики дійсно інноваційної парадигми освіти 4.0.

Характерними особливостями сьогодення $\epsilon$ істотне збільшення обсягу науковотехнічних знань і відповідне зростання темпу їх засвоєння суб' єктами освіти. В традиційній же парадигмі освіти, в рамках поширеної системи 3.0, ця проблема вирішується шляхом організації безперервної освіти під час всього активного трудового життя. Але це рішення 3 плином часу стає непродуктивним. Тож не випадково Р. Акофф впевнено стверджує, що “освіта епохи систем повинна здійснюватися в здатних навчатися i адаптуватися системах освіти" [1, с. 194]. Саме такими і стають найкращі університети світу, які сповідують ідеологію 4.0. Вони ж водночас інтенсивно розвивають важливі дослідження на проривних напрямках науки і техніки, здійснюючи гідний внесок в інноваційний розвиток нашої цивілізації.

Прискорена трансформація результатів наукових відкриттів і розробок в конструкції й технології відкриває перед цими університетами реальні можливості істотно поповнювати свої бюджети. Їхнім успіхам сприяють i процеси помітного скорочення циклу морального старіння техніки і технологій, загострення конкуренції на ринку інновацій. Правда, конкуренція часто може виступати і певним гальмом на шляху впровадження новітніх прогресивних технологій, яке загрожує зниженням прибутку тим, хто виявляється не готовим або не прагне використовувати інновації.

Справді інноваційна концепція формування такої еліти свого часу була розроблена науковцями Національного технічного університету "Харківський політехнічний інститут". Авторами концепції виступили професори Л. Товажнянський, О. Пономарьов, та О. Романовський [6]. Основними ідеями концепції були визначені такі положення. Поперше, забезпечення високої професійної компетентності майбутніх інженерів у поєднанні $з$ розвиненими креативними здібностями. Це поєднання повинно забезпечувати інноваційну спрямованість їхньої майбутньої професійної діяльності та успішну їхню професійну й особистісну самореалізацію.

По-друге, рішуче подолання технократичного характеру мислення майбутніх фахівців та прищеплення їм системи гуманістичних життєвих цілей i цінностей. По-третє, формування багатого духовного світу і розвиток їхньої високої загальної та професійної культури. По-четверте, прищеплення майбутнім інженерам міцних навичок командної діяльності, норм ділової етики і прагнення підтримувати сприятливий психологічний клімат у колективі. По-п'яте, посилення фундаментальної підготовки як основи загальноінженерних та спеціальних навчальних дисциплін, інноваційних інженерних рішень. Пошосте, прищеплення студентам логікометодологічної компетенції, яка сприяє організації професійної діяльності фахівців на принципах наукової організації праці та їі спрямованості на забезпечення високої ефективності, інноваційності та конкурентоспроможності фірми або підприємства і його продукції.

Таким чином, організація освітнього 
процесу на нормах і принципах цієї концепції фактично означає істотне просування університету шляхом його переходу на рівень освіти 4.0. Тим більше, що ця концепція забезпечує практичну спрямованість професійної підготовки фахівців, їхню психологічну готовність до успішного здійснення ними завдань i функцій своєї професійної діяльності. До того ж, вкрай важливою $є$ i така спрямованість концепції, як екологізація техніки і технологій та природозбереження.

Найстаріший навчальний заклад інженерного профілю України Національний технічний університет "Харківський політехнічний інститут” за свою більш ніж 135-річну університет завоював високий авторитет в нашій країні і в десятках країн світу. Про це свідчить прагнення багатьох іноземних громадян здобути освіту в нашому університеті. Його відрізняють високий рівень професійної підготовки фахівців і чутливість до інновацій, до зміни кадрових потреб різних сфер суспільного життя. Підтримуючи тісні партнерські відносини 3 десятками зарубіжних закладів вищої освіти, університет щедро ділиться своїм досвідом і переймає все нове i прогресивне у своїх партнерів.

Його вважають одним із кращих університетів України відповідно до показників Світового рейтингу University Impact Rankings 2021, який оцінює глобальні успіхи закладів вищої освіти в досягненні Цілей сталого розвитку, проголошених ООН. Зокрема, НТУ “ХПІ” посів перше місце серед українських вишів у таких категоріях, як “промисловість, інновації та інфраструктура" і “гідна праця та економічне зростання”. Взагалі у 2021 році університет розширив до восьми кількість категорій рейтингу, для яких він подавав відповідну інформацію. Саме інноваційна спрямованість діяльності нашого університету і виступає однією 3 визначальних передумов успішної підготовки справжньої еліти та лідерів-професіоналів для промисловості 4.0 та інших сфер суспільного життя країни.

Наведена інформація виступає переконливим свідченням того, що наш університет вже готується переходити до освітньої парадигми 4.0 з тим, щоб забезпечувати якість підготовки фахівців взагалі, справжньої гуманітарно-технічної еліти і успішних ефективних лідерів відповідно до потреб та вимог промислової революції 4.0 .
Висновки 3 даного дослідження i перспективи подальших розвідок у даному напрямку. Результати дослідження дозволяють дійти таких висновків.

1. Сучасний світ стрімко змінюється, набуваючи виразно інноваційного характеру й ускладнюючи як зміст і технології суспільного виробництва, так і спосіб індивідуального i суспільного життя людей. Розвиток інформаційних та біокібернетичних технологій i штучного інтелекту прискорює становлення економіки на основі промисловості четвертого покоління (IR 4.0). Це істотно змінює суспільні вимоги до системи освіти стосовно підготовки адекватного кадрового забезпечення всіх сфер суспільного виробництва.

2. Відповідно до нових суспільних вимог вища школа має кардинально переглянути цілі, зміст і характер підготовки фахівців. Індустрія 4.0 вимагає нової якості кадрів, що зумовлює потребу в новій освітній парадигмі на рівні 4.0. Ці фахівці повинні не тільки швидко адаптуватися до змін, а й самі мають творити зміни, забезпечувати конкурентоспроможність результатів своєї діяльності, а відтак і свою конкурентоспроможність на ринку праці.

3. Певна інерційність, притаманна самій природі людини, стає причиною неготовності більшості людей до активного життя й діяльності в умовах інноваційного розвитку. Тому суспільство відчуває потребу в лідерах, які 6 активізували людей i надихали їх на ефективну спільну діяльність, яка б сприяла зростанню їхнього добробуту, позитивного соціально-психологічного самопочуття і формуванню готовності до змін і участі в інноваціях. Лідери у своїй діяльності спираються на еліту як кращих професіоналів i носіїв моральності й корпоративної культури.

4. Надзвичайна суспільна важливість еліти і лідерства і специфіка тих функцій, які ім доводиться виконувати, вимагають організації системи їхньої цільової підготовки. Як свідчить практичний досвід нашого університету, таку підготовку доцільно здійснювати в умовах закладу вищої освіти інженерного профілю. Дійсно, його зв'язок із виробництвом, участь у розвитку індустрії 4.0 створює не тільки чіткі орієнтири для переходу до освіти 4.0, а й технічні та технологічні передумови підготовки еліти і лідерів рівня 4.0. Перспективами подальших досліджень 
вважаємо визначення доцільних педагогічних технологій, логіко-методологічних засад i науково-методичного забезпечення освітнього процесу ефективної цільової підготовки

\section{Список літератури:}

1. Акофф Р. Акофф о менеджменте (Серия “Теория и практика менеджмента") / Р. Акофф // пер. с англ. - СПб. : Питер. - 2002. - C. 448

2. Виханский O. С. Стратегическое управление / О. С. Виханский // учебник. - 2-е изд., переб. и доп.-М. :Гардарики.-1999.-С. 296

3. Гандапас Р. Харизма лидера / Р. Гандапас. - М.: Манн, Иванов и Фербер. 2013. - C. 224

4. Романовський О. Г. Парадокси харизматичного лідерства / О. Г. Романовський, O. С. Пономарьов // Теорія i практика управління соціальними системами. - 2017. №1. - С. 47-56

5. Сокол Є. І. Підготовка професіоналів-лідерів як завдання вищої школи / С. I. Сокол // Лідер. Еліта. Суспільство. - 2017. - № 1. - C. 16-22

6. Товажнянський Л. Л. Концепція формування гуманітарно-технічної еліти в НТУ “ХПІ" та шляхи іiі реалізації / Л. Л. Товажнянський, О. Г. Романовський, О. С. Пономарьов. - Харків : НТУ "ХПІ". 2004. - C. 416

7. Агудело О. Л. Гнучкі маршрути навчання на основі концептуальних карт / О. Л. Агудело, Дж. Салінас // Нові підходи в освітніх дослідженнях. - 2015. - Вип. 4. - № 2. - С. 70-76

8. Бас Б. М. Трансформаційне лідерство / Б. М. Бас, Р. Е. Ріджіо. - 2-е вид. - НьюЙорк : видавництво Lawrence Erlbaum Associates. - 2006. - C. 282

9. Касс П. Філософія для креативного лідерства: як філософія може перетворити людей на більш ефективних лідерів / П. Касс, П. Г. Клодель. - Athena Press. - 2007. - С. 280

10. Конгер Дж. А. Харизматичне лідерство в організаціях: сприйняті поведінкові атрибути та їх вимірювання / Дж. А. Конгер, Р. Канунго // Журнал організаційної поведінки. - 1994. - №15. - С. 439- 452

11. Клопп М. “Навчання 4.0”. Концептуальна дискусія. 2018 IEEE. / М. Клопп, Дж. Абке // Міжнародна конференція 3 викла- справжньої виробничої еліти й високопрофесійних керівників-лідерів, яким притаманна належна професійна компетентність у відповідній технічній сфері.

дання, оцінювання та навчання для інженерії (TALE). - 4-7 грудня 2018 р. - Вуллонгонг, Новий Южний Уэльс, Австралія. - С. 671-876

12. Садегі А. Роль лідерства, орієнтованого на знання, в управлінні знаннями та інноваціях [електронний ресурс] / А. Садегі, Ф. Мостафаві Рад // Наукові листи менеджменту. - 2018. - С. 151-160. - Режим доступу: doi: 10.5267/j.msl.2018.1.003

13. Шахрум А. А. Промислова революція 4.0 та освіта / А. А. Шахрум, Н. Хусін // Міжнародний журнал академічних досліджень у сфері бізнесу та соціальних наук. 2018. - №8(9), 314-319.

14. Вермільйон С. Д. Дослідження формування результатів і ставлення до ризику в інженерних рішеннях в умовах невизначеності / С. Д. Вермільйон, Р. Дж. Малак, Р. А. Смолмен // Журнал механічного проектування. - 2015. - № 137. - Вип. 8

15. Занда С. Побудова ефективного менеджменту та практики лідерства / С. Занда // Інновації, технології та управління знаннями. - 2018

\section{References:}

1. Akoff, R. (2002), "Akoff on management"; Management Theory and Practice Series, lane with English, SPb .: Peter, p. 448

2. Vikhansky, O. S. (1999), "Strategic management: a textbook", 2nd ed., Reworked. and ext., M .: Gardariki, p. 296

3. Gandapas, R. (2013), "Charisma of the leader", M .: Mann, Ivanov and Ferber, p. 224

4. Romanovsky, O. G., Ponomarev, O. S. (2017), "Paradoxes of charismatic leadership", Theory and practice of social systems management, no. 1. pp. 47-56

5. Sokol, E. I. (2017), "Training of professional leaders as a task of higher school", Leader. Elite. Society, no. 1. pp. 16-22

6. Tovazhnyansky, L. L., Romanovsky, O. G., Ponomarev, O. S. (2004), "The concept of formation of the humanitarian and technical elite in NTU "KhPI" and ways of its implementation", Kharkiv : NTU "KhPI", p. 416

7. Agudelo, O. L., Salinas J. (2015), 
"Flexible Learning Itineraries Based on

Conceptual Maps", New approaches in educational research, vol. 4, no. 2, pp. 70-76

8. Bass, B. M., Riggio, R. E. (2006), "Transformational leadership", 2nd ed. N.Y. : Lawrence Erlbaum Associates Publishers, p. 282

9. Casse, P., Claudel, P. G. (2007), "Philosophy for Creative Leadership: How philosophy can turn people into more effective leaders", [S.p.] : Athena Press, p. 280

10. Conger, J. A., Canungo, R. (1994), "Charismatic leadership in organizations: Perceived behavioral attributes and their measurement", Journal of Organizational Behavior, no. 15, pp. 439-452

11. Klopp, M., Abke, J. (2018), ““'Learning 4.0”. A conceptual Disscussion. 2018 IEEE", International Conference on Teaching, Assessment and Learning for Engineering
(TALE), 4-7 December 2018, Wollongong, NSW, Australia, pp. 671-876

12. Sadeghi, A., Mostafavi Rad, F. (2018), "The role of knowledge-oriented leadership in knowledge management and innovation", Management Science Letters, pp. 151-160, available at: doi: 10.5267/j.msl.2018.1.003

13. Shahroom, A. A., Hussin, N. (2018), "Industrial Revolution 4.0 and Education", International Journal of Academic Research in Business and Social Sciences, no. 8(9), pp. 314-319

14. Vermillion, S. D., Malak, R. J., Smallman, R. A. (2015), "Study on Outcome Framing and Risk Attitude in Engineering Decisions Under Uncertainty", Journal of Mechanical Design, vol. 137, issue 8

15. Zanda, S. (2018), "Building Efficient Management and Leadership Practices", Innovation, Technology and Knowledge Management 